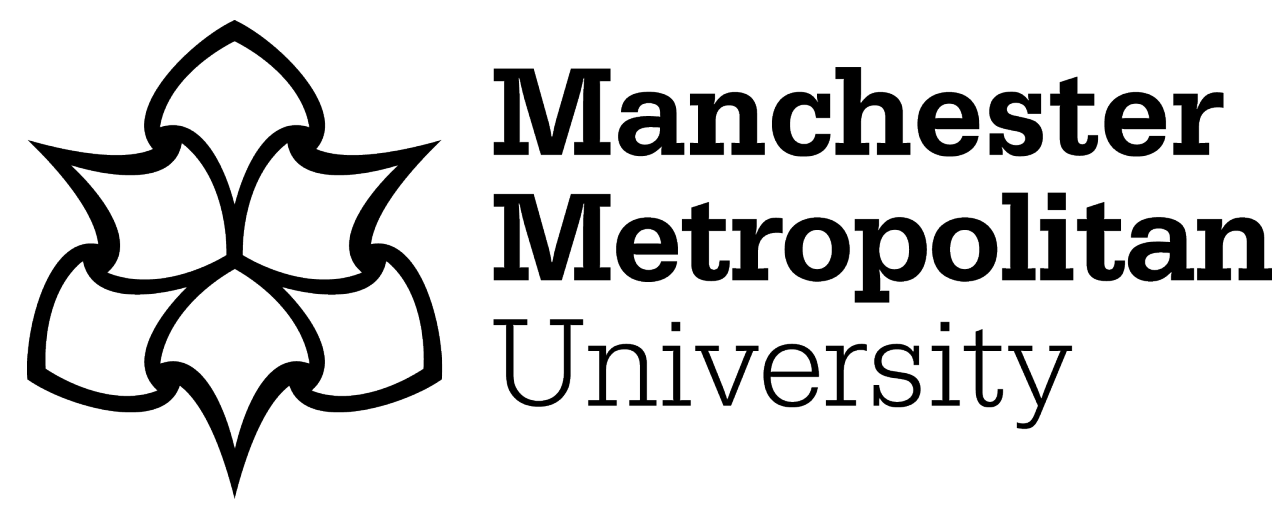

Okunola, OM, Rowley, J and Johnson, F (2017) The multi-dimensional digital divide: Perspectives from an e-government portal in Nigeria. Government Information Quarterly, 34 (2). pp. 329-339. ISSN 0740-624X

Downloaded from: https://e-space.mmu.ac.uk/618354/

Version: Accepted Version

Publisher: Elsevier

DOI: https://doi.org/10.1016/j.giq.2017.02.002

Usage rights: Creative Commons: Attribution-Noncommercial-No Derivative Works 4.0

Please cite the published version 


\title{
The multi-dimensional digital divide: perspectives from an e-government portal in Nigeria
}

\begin{abstract}
There is a widespread recognition that a digital divide exists between countries and individuals, and that understanding and addressing that divide is pivotal to the empowerment of citizens. Furthermore, although governments have often seen e-government services as one means of eroding the digital divide, prior research into the digital divide in the e-government context is limited. Hence, this research seeks to contribute to understanding of the nature of the digital divide as it affects Nigerian citizens, specifically users of the Nigeria Immigration Service (NIS) web portal. The NIS portal is a rich context in which to study the digital divide: it is the most welldeveloped e-government service in Nigeria; its use is compulsory for citizens seeking to travel outside of Nigeria; and, its users reside within both Nigeria (a developing country) and in more developed countries, such as the US and the UK. Using an online survey, and snowball sampling, 351 completed questionnaires were collected and analysed using t-tests and Anova. The digital divide was represented in terms of the three dimensions: previous Internet experience, access to computing facilities, and previous e-government experience. Analysis demonstrated a multi-dimensional digital divide with demographic, social-economic, and locational factors affecting egovernment users' internet experience, their access to computing facilities and their e-government experience. Overall, this research offers insights into the complexity of the digital divide.
\end{abstract}

Keywords: e-government; digital divide; gender; developing countries; immigration services; education 


\section{Introduction}

The digital divide has been recognised as relating to inconsistencies between individuals, households, businesses and geographical locations with regard to their access to resources and computing facilities, and to their use of information and communication tools, including the internet (Organisation for Economic Co-operation and Development [OECD], 2001; Wanasika, 2003; Prahalad, 2004; Norris, 2006; Po-An Hsieh, Rai \& Keil, 2008; Tayo, Thompson \& Thompson, 2015). It also refers to a discrepancy between those having the skills, knowledge and capabilities to utilise technologies and those who do not (Jurich, 2000; Cullen, 2001; Sitawa-Ogutu \& Rege, 2010; Hall \& Owens, 2011). The extent of the digital divide can be affected by various demographic, socioeconomic and locational variables, including gender, age, education, employment, income and location. Whilst there is a widespread recognition that the digital divide can exist within countries, with, for example, in developed countries, older or less well-educated groups having a lower level of access to computing technologies and the internet as well as a lower level of skills (e.g. Bertot, 2003; Sitawa-Ogutu \& Rege, 2010; Hall \& Owens, 2011), one of the most explored research areas relates to the digital divide between countries. This focus represents an acknowledgement that numerous developing nations, including Nigeria, as well as China, Russia and Brazil, are lagging behind in their efforts to reduce the digital-divide with low levels of internet utilisation and restricted development of e-commerce (Bertot, 2003; Akanbi \& Akanbi, 2012; Forum for East Asia-Latin America Cooperation [FEALAC], 2014). In particular, many developing countries have significant challenges in developing their information and communication technology infrastructure (Vu, 2011; Gomez \& Panther, 2012). However, on the other hand, such technologies are seen as having the potential to provide opportunities, support economic growth and increase democracy in such countries (Shirazi, Ngwenyama \& Morawczynski, 2010).

Given both the challenges and opportunities associated with a strong information and communications infrastructure, some developing countries have invested in innovation concerned with e-government services not only as an opportunity to streamline and improve access to government information, services, and political and policy making processes, but also as a means of investing in technology infrastructure and developing the 
computer and internet skills of their populations (Chinn \& Fairlie, 2006; Bélanger \& Carter, 2009; Vicente \& López, 2011). As these are viewed as important initiatives, there is a growing body of research reporting on egovernment projects in developing countries. Some of these studies comment on the digital divide, but a number of authors have called for further study of the nature of the digital divide in the context of e-government, suggesting that there is a specific need for such research in developing countries and specifically, Africa. (Chatfield \& Alhujran, 2009; Yonazi, Sol \& Boonstra, 2010; Al-Shboul et al., 2014). Accordingly, there is scope for further research into the nature of the digital divide in different countries and across a range of e-government initiatives.

More specifically, the limited studies on the digital divide in Africa, demonstrate that Africa faces a high level of inequality, a weak IT communication system, particularly in rural areas, and a lack of willingness to invest in ICT with a view to address related issues on the part of governments (Thompson \& Walsham, 2010). Nkwe (2012) and Nkohkwo \& Islam (2013) suggest that this low level of internet penetration and inadequate telecommunication and technological infrastructure in Africa contributes to a digital divide regarding e-government services implementation. This is especially important as the digital divide is interrelated with social, political, educational and economic issues and can potentially reproduce existing social disparities. Hence, this research is based on an egovernment portal provided in one of the larger African countries, Nigeria. Nigeria has been chosen as the context for this study because not only is it a large developing country, with considerable wealth, but also has considerable challenges in both developing IT infrastructure and in educating its very large population. The e-government service that is used as the basis of the study is the Nigeria Immigration Service (NIS) portal. This is the most welldeveloped e-government service in Nigeria, and its use is compulsory for citizens seeking to travel outside of Nigeria. Also, given its focus on immigration, it is possible to compare the profiles and views of Nigerian citizens who are resident inside and outside of Nigeria. The opportunity to make this comparison is a unique aspect of this study. The aim of this study is, then, to explore the effect of demographic, socio-economic, and locational factors on the dimensions of the digital divide: access to computing facilities, previous internet experience, and previous e- 
government experience. On this basis, the Multi-Dimensional Digital Divide Model (MDDDM) is proposed and recommendations are offered for further research and practice.

The remainder of this article is structured as follows. The following section presents the theoretical background for proposing a multi-dimensional digital divide model, with two distinct facets, the components of the divide, and the factors that impact on those factors, and undertakes hypothesis development. In Section 3, the research approach for empirically testing the hypotheses is presented. Next, the findings from the research, based on both descriptive statistics and hypothesis testing, are presented and discussed. Finally, conclusions and recommendations for further research and practice are presented.

\section{Theoretical background and hypotheses}

\subsection{Defining the digital divide}

This study focuses on the digital divide in the use of e-government services. According to Norris (2000), Cullen (2001) and Hall \& Owens (2011), the digital divide is the technology gap between individuals with access to computerised technology and those with constrained, or no means of access, although Brandtzæg, Heim \& Karahasanović (2011) offer a slightly broader definition suggesting that the digital divide can be characterised as unequal access to computing facilities. Other authors have recognized that the digital divide also has a dimension that is associated with the skills to make use of computing technology (Min, 2010; Van Deursen \& Van Dijk, 2010). Yet other authors refer to the digital divide in terms of the demographic variables that, may for example, influence the level of access to computing facilities or technology skills, focusing for instance on gender (Antonio \& Tuffley, 2014), income (Servon \& Nelson, 2001) or broader concepts such as socio-economical advantage and disadvantage (Hsieh, Rai \& Keil, 2008). Indeed, one of the difficulties in building a coherent body of knowledge regarding the digital divide is the inclusion of both access and skills and the demographics that might influence access and skills (Sylvester \& McGlynn, 2010). This research incorporates both types of variables into the proposed Multi-Dimensional Digital Divide Model (MDDDM) and explores some of the relationships between 
them. More specifically, it includes previous internet experience, and previous e-government experience as pseudoindicates of level of skill, along with access to computing facilities. In terms of demographic variables it includes: location, gender, age, education, employment and income.

\subsection{Demographic factors influencing the extent of the digital divide}

Previous research indicates that location, demographic factors (gender, age), and socio-economic factors (education, employment and income) contribute to the digital divide.

Location, specifically with regard to the differences between urban and rural areas has long been recognised to contribute to the digital divide (Hindman, 2000; Norris, 2000). Recent research shows that there is a persistent digital divide between those living in rural and urban areas with higher level of Internet usages amongst urban communities (Sitawa-Ogutu \& Rege, 2010; Warschauer, 2012; White 2012; Banihashemi \& Rejaei, 2015; Park \& Kim, 2015). Furuholt and Kristiansen (2007) argue that there is more public internet access points in urban areas compared to the rural areas; this forms the basis for a digital divide based on location. One reason for this may be the concentration of Internet Service Providers (ISPs) in urban centres. Another strand of research on location considers the gap between developed and developing countries, both in terms of technology infrastructure and in terms of computing and Internet skills, with affordability of Internet connection for users in developing countries with a low standard of living (Guillén \& Suárez, 2005; White (2012; Banihashemi \& Rejaei, 2015; Park \& Kim, 2015). Guillén \& Suárez, 2005 in their study found factors such as cost of internet, regulations, political and social issues have effect on Internet growth in both developed and developing countries which results in different level of internet use between developed and developing countries. White (2012) argued that not everyone has easy access to internet connectivity and that there is a wide gap between cities and rural areas, race, rich and poor when it comes to access to computer or internet. Banihashemi \& Rejaei, (2015) argued that third world countries and most especially Muslim countries affected by the digital divide. Park \& Kim, 2015 examined rural digital exclusion and found that improvement in infrastructure development can improve the problem of digital divide. 
There has also been considerable interest in identifying the effect of demographic variables, such as gender and age on the digital divide. Wasserman \& Richmond-Abbott (2005) and Antonio \& Tuffley (2014) revealed that males constitute a significantly larger percentage of internet users than females. However, Fallows (2005) and Hilbert (2011) suggest that there is a relationship between gender and age, since their study showed that younger women outpace their male counterparts regarding computer usage. As regards age, there is considerable evidence that age affects access to and level of use of computer and Internet facilities in both developing (Nwalo, 2000; Idowu \& Adagunodo, 2004) and developed countries (Loges \& Jung, 2001; Hoofnagle et al., 2010; Lenhart et al.'s,2010). This could be because older people tend to have less enthusiasm for technology than younger people. Heart \& Kalderon (2013) also believe that older age groups lag behind in the adoption of ICT compared to younger age groups.

The other group of variables that affect the nature and extent of the digital divide are social-demographic variables, including education, employment and income. Kiiski \& Pohjola (2002) and Vicente \& López (2011) argue that education is important for growth and development, and, in addition, is the most consistent global predictor in measuring experience and access to internet technology. According to Zhong (2011), ICT has helped countries increase their literacy levels, as the internet has become an important medium in the learning process for students, especially in colleges, universities and technical institutes. Wilson, Wallin \& Reiser (2003) and Chinn \& Fairlie (2006) suggest that highly educated people keep up-to-date with technology developments, enjoy easy access to the internet and tend to be more experienced users than people who have received little education.

Employment status also impacts on internet access and internet experience. Rustad \& Paulsson (2005) argue that if the nature of an employee work is internet-related, then they have more experience regarding its use than others. Often associated with income is income level. Individuals who earn high incomes usually enjoy easy access to both 
information and communication technology, and the internet. Servon \& Nelson (2001), Warschauer (2002, 2012), van Dijk \& Hacker (2003) and Chakraborty \& Bosman (2005) argue that people's income status may have a significant effect on internet access as people with low incomes, often have difficulty in being able to afford internet connections. Fuchs (2008) also mentions that people on low incomes face affordability issues when it comes to internet access.

On the basis of the previous research summarized above, the hypotheses in Table 1 are proposed. These hypotheses are incorporated into this study's research model as shown in Figure 1.

\begin{tabular}{|c|c|c|}
\hline Hypothesis & Variable & Path Coefficient \\
\hline H1 & \multirow{6}{*}{ Location } & Location (rural / urban) affects access to computing facilities \\
\hline $\mathrm{H} 2$ & & Location (rural / urban) affects internet experience \\
\hline H3 & & Location (rural / urban) affects e-government experience \\
\hline $\mathrm{H} 4$ & & Location (inter-country) affects access to computing facilities \\
\hline $\mathrm{H} 5$ & & Location (inter-country) affects internet experience \\
\hline H6 & & Location (inter-country) affects e-government experience \\
\hline $\mathrm{H7}$ & \multirow{3}{*}{ Gender } & Gender affects access to computing facilities \\
\hline $\mathrm{H} 8$ & & Gender affects internet experience \\
\hline H9 & & Gender affects e-government experience \\
\hline $\mathrm{H} 10$ & \multirow{3}{*}{ Age } & Age affects access to computing facilities \\
\hline H11 & & Age affects internet experience \\
\hline $\mathrm{H} 12$ & & Age affects e-government experience \\
\hline $\mathrm{H} 13$ & \multirow{3}{*}{ Education } & Education affects access to computing facilities \\
\hline $\mathrm{H} 14$ & & Education affects internet experience \\
\hline $\mathrm{H} 15$ & & Education affects e-government experience \\
\hline $\mathrm{H} 16$ & \multirow{3}{*}{ Employment } & Employment affects access to computing facilities \\
\hline $\mathrm{H} 17$ & & Employment affects internet experience \\
\hline $\mathrm{H} 18$ & & Employment affects e-government experience \\
\hline H19 & \multirow{3}{*}{ Income } & Income affects access to computing facilities \\
\hline $\mathrm{H} 20$ & & Income affects internet experience \\
\hline $\mathrm{H} 21$ & & Income affects e-government experience \\
\hline
\end{tabular}

Table 1: Hypotheses

Insert Figure 1 here 


\section{Method}

\subsection{Research context}

Nigeria has been seeking to develop its e-government services since the early 1990's (Abdulkareem, 2015), and in 2001, the 'Nigerian National Policy for Information Technology', was launched as part of an integrated approach to achieving e-government development within the Federal Government of Nigeria (Jidaw System Limited, 2011). Nigeria's e-government system aims to enhance internal efficiency, public services and democratic processes in the legislation and administration section of the public sector (Mundy \& Musa, 2010; Adeyemo, 2011). By providing a funding mechanism for governmental organisations, the Nigerian government's ambition is to extend egovernment implementation from federal government departments to both state and local government public services with a view to initiating a programme aimed at enhancing computer access across the country (Adeyemo, 2011).

However, progress with citizen adoption of e-government in Nigeria, as in many other developing countries, has been hindered by poor technology infrastructure, including poor internet connectivity and unreliable electricity supplies (Adeniran, 2008; Abdulkareem, 2015). In addition, it has problems with low ICT literacy levels, theft and vandalization of ICT equipment, privacy and security concerns and the absence of interconnection between government portals (Olufemi, 2012; Abdulkareem, 2015). There is an increasing use of the mobile internet (NCC, 2015; Oduneye, 2015), which suggests that mobile e-government is a potential way forward. However, at the present time, the number of fixed and wireless broadband internet subscriptions is still very low, especially in rural areas, where most users rely on cybercafé for internet access (Kuboye, Alese and Imasuen, 2012; Abdulkareem, 2015).

The context of this study is the e-government service offered by the Nigeria Immigration Service (NIS). The NIS controls and monitors entry and exit activities in Nigeria. It has developed its e-services to support information distribution among citizens, form processing and financial transactions, including online payment for new 
passports, passport renewals, and visa applications and processing as well as the processing of other entry permits

(Kanat and Ozkan, 2009). The NIS e-service portal is a particularly interesting context for study because it can be accessed by citizens and non-citizens and by people whose main country of residence is either Nigeria or elsewhere. In addition, the website offers information and supports transactions and unlike some other egovernment services, if someone wishes to move in and out of Nigeria its use is mandatory. In addition, whilst there is evidence that Nigeria is facing significant challenges in the implementation of e-government (Akunyili, 2010; Fatile, 2012; Omeire \& Omeire, 2014), the NIS is acknowledged to be one of the few successful egovernment implementations in the country.

\subsection{Research approach and data collection}

This research adopted a quantitative online survey-based approach to test the research model as respondents were scattered across the globe, and given the diversity of the population a reasonably large sample was judged to be essential (Creswell, 2009). The questionnaire comprised mainly closed questions to support ease of completion and analysis. This included demographic data (gender, age, education, income, employment sector, country of permanent residence and localisation (rural or urban dwellers) and data on access to computing facilities, previous internet experience, and previous experience of use of e-government. Questions on access to computing facilities invited 'Yes/No' responses; they are informed by literature on e-government that discusses the technologies used (e.g. Abdulkareem, 2015; Kuboye et al., 2012). Questions on previous internet and e-government experience were Likert style questions, based on frequency of use: 'never (1), rarely (2), occasionally (3), frequently (4), very frequently (5); they focus on previous experience, a measure that has been used by other authors (e.g.Colesca \& Dobrica, 2008). In respect of the questions on access to computing facilities, previous Internet experience, and previous e-government experience, the researchers faced a dilemma regarding the selection of appropriate items to accommodate the situation on both developed countries such as the US and UK and in Nigeria. In seeking to compare two groups in different contexts there are always some compromises to be made; the researchers carefully 
considered, for example, the range of technology options available for both groups, and sought to develop a range of items that covered most scenarios.

\subsection{Sampling and respondents}

Non-probability sampling, based on snowball sampling was used to access respondents residing in different parts of the world. These respondents identified themselves as users of the NIS portal. They will have accessed this portal through different technologies, including: mobile phones and computers at cybercafes. (Table 3). Snowball sampling does have a number of limitations, including the potential to over-sample a particular group, and the possibility that a participant can respond more than once. However, there was no evidence of either type of bias. Sampling was continued until a dataset sufficiently large to support relevant analyses had been gathered. Ultimately, valid 411 questionnaires were submitted.

The demographic profile of respondents is summarized in Table 2. Whilst the data was gathered through snowball sampling, the respondent sample showed a good balance with respect to gender (Male 50.1\% v Female 49.9\%) and place of residence (Nigeria 50.4\% v Other 49.6\%). All respondents were in the age range of 18 to 65 years and were fairly evenly distributed between age categories. Education levels varied, but overall the sample was relatively well educated. This, and the high level of employment, may be a limitation of this research in terms of fully exploring the digital divide. In addition, the number of respondents in rural locations (mostly resident in Nigeria) is lower than would be optimal, but again this is a reflection of the situation in which access to information technologies is more limited in rural areas in Nigeria (Imhonopi \& Urim, 2015; Abdulkareem, 2015). It must also be acknowledged that the online survey approach adopted is predisposed to capture a more digitally empowered demographic.

\section{Demographic Profile of Respondents}

\begin{tabular}{|c|c|c|c|}
\hline Location (Country) & $\%$ & Gender & $\%$ \\
\hline Nigeria & 50.4 & Male & 50.1 \\
\hline Other (this include UK, US, Canada etc) & 49.6 & Female & 49.9 \\
\hline Location (Urban/Rural) & & Age & $\%$ \\
\hline
\end{tabular}




\begin{tabular}{|c|c|c|c|}
\hline Urban & 84.6 & Young (18 -30yrs) & 28.1 \\
\hline Rural & 15.4 & Middle (31 to $50 \mathrm{yrs})$ & 52.4 \\
\hline \multicolumn{2}{|l|}{ 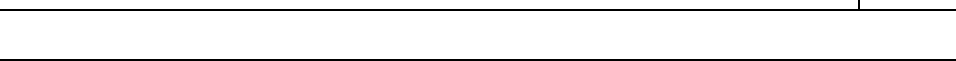 } & Older (51yrs and above) & 19.5 \\
\hline \multicolumn{2}{|l|}{ Education Status } & & \\
\hline Well educated (PhD and Masters) & 25.7 & Employment Status & \\
\hline Moderately Educated (Bachelors and HNDs) & 57.5 & Government Employee & 16.5 \\
\hline Fairly Educated (Diploma, Technical, School) & 16.5 & Private Sector Employee & 32.8 \\
\hline \multirow[t]{2}{*}{ Not Formally educated } & 0.3 & Self Employed & 23.9 \\
\hline & & Unemployed & 6.3 \\
\hline Income Level & & Retiree & 0.9 \\
\hline Low & 44.2 & Student & 19.6 \\
\hline Medium & 33.3 & & \\
\hline High & 22.5 & & \\
\hline
\end{tabular}

\section{Table 2: Demographic profile of respondents}

\subsection{Data analysis}

Prior to conducting the statistical analysis on the variables, the suitability of data was checked. Cronbach's Alpha was calculated for each variable to ensure that the scales were reliable and consistent (Pallant, 2016). The Cronbach's Alpha coefficients were: access to computing facilities (0.87); previous internet experience (0.86); previous e-government experience (0.94). These values show all measurement scales to be either good or excellent, with good internal consistency and data suitability (Pallant, 2016).

Independent t-tests and a one-way analysis of variance (ANOVA) were used to investigate the relationships identified in the hypotheses. Independent sample t-test was used to compare mean scores when there were two different groups of respondents or conditions, to identify if there is a statistically significant difference in their mean scores (Pallant, 2010). An ANOVA test was used to compare mean scores when there were more than two groups or populations (Pallant, 2010). In conducting both an independent t-test and an ANOVA test, the magnitude of the effect size is important; this provides an indication of the magnitude of differences between groups in both the t-test and ANOVA, to ensure that the difference in mean scores has not occurred by chance (Pallant, 2010). The eta squared and Cohen's $d$ is the most commonly used effect size formulas and benchmarks (Pallant, 2010). The Cohen's $d$ effect size guidelines were: small $=0.01$ to $<0.06$; medium $=0.06$ to $<0.14$; large $=0.14$; these were 
used to interpret values of effect size (Cohen, 1988). In addition, Levene's Test for the Equality and Homogeneity of Variances were checked to determine the spread of group data, as well as whether data are identical. In the case of ANOVA test, if the sig. value for Levene's test is larger than 0.5 , its assumption of the homogeneity of variance has not been violated. As a result, the Tukey HD post-hoc test were used for the multiple comparisons of the group to determine the statistically significant difference in the mean scores between each pair of groups. However, if the sig. value for Levene's test is less than 0.5 , then its assumption of homogeneity of variance has been violated and the Games-Howell post-hoc test were used as a result (Morgan et al., 2013).

\section{Findings}

\subsection{Descriptive statistics}

\subsubsection{Access to Computing Facilities}

Access to computing facilities was measured using the 11 items shown in Table 3 . Looking at the 'All' column, it is evident that $98.6 \%$ of the respondents had access to a mobile phone compared to $42.2 \%$ who had access to a landline telephone. Additionally, over $50 \%$ of the respondents had access to a computer and the internet in each of the suggested locations of home, work or school, and cyber cafes. However, only $49.3 \%$ said that they had access to an uninterrupted electricity supply.

More detailed analyses of access to computing facilities on the basis of the place of residence (location) are shown in the other columns in Table 3. Most significantly, there was a significant use of mobile phones across all groups, with $92.6 \%$ of Nigeria Rural, $100 \%$ of Nigeria Urban, and $99.1 \%$ of UK \& USA respondents confirming that they had access to a mobile telephone. In contrast, only $3.7 \%$ of respondents had access to a landline telephone in Nigeria Rural, while $11.4 \%$ of Nigeria Urban had access to a landline telephone and $79.3 \%$ of the respondents living in both the UK and the USA had access to one, showing the significant difference between Nigeria and the two developed nations. Also, $93.7 \%$ and $83.8 \%$ of the respondents living in both the UK \& the USA respectively had access to a computer (desktop, laptop and tablet) and the internet at home and work or school, compared to 
$39 \%$ and $65.5 \%$ of the respondents living in rural or urban Nigeria respectively. This analysis shows that $81.4 \%$ of the respondents living in Nigeria, in the rural and urban categories, had access to a computer at a cybercafe, compared to $33.3 \%$ of the respondents living in the UK and the USA. The poor level of access to computer facilities among the Nigerian respondents is reflected in their access to the internet, as at least $80 \%$ relied on cybercafes to access the internet, compared to $31.5 \%$ of the respondents living in the UK and the USA. Over $50 \%$ of the respondents living in Nigeria in the rural and urban categories had access to the internet through their mobile telephones. However, only $6.8 \%$ of the respondents living in Nigeria in the rural and urban categories said that they had access to an uninterrupted electricity supply, compared to $93.7 \%$ of the respondents living in both the UK and the USA. This has a significant potential for difficulties and inconvenience in accessing e-government services.

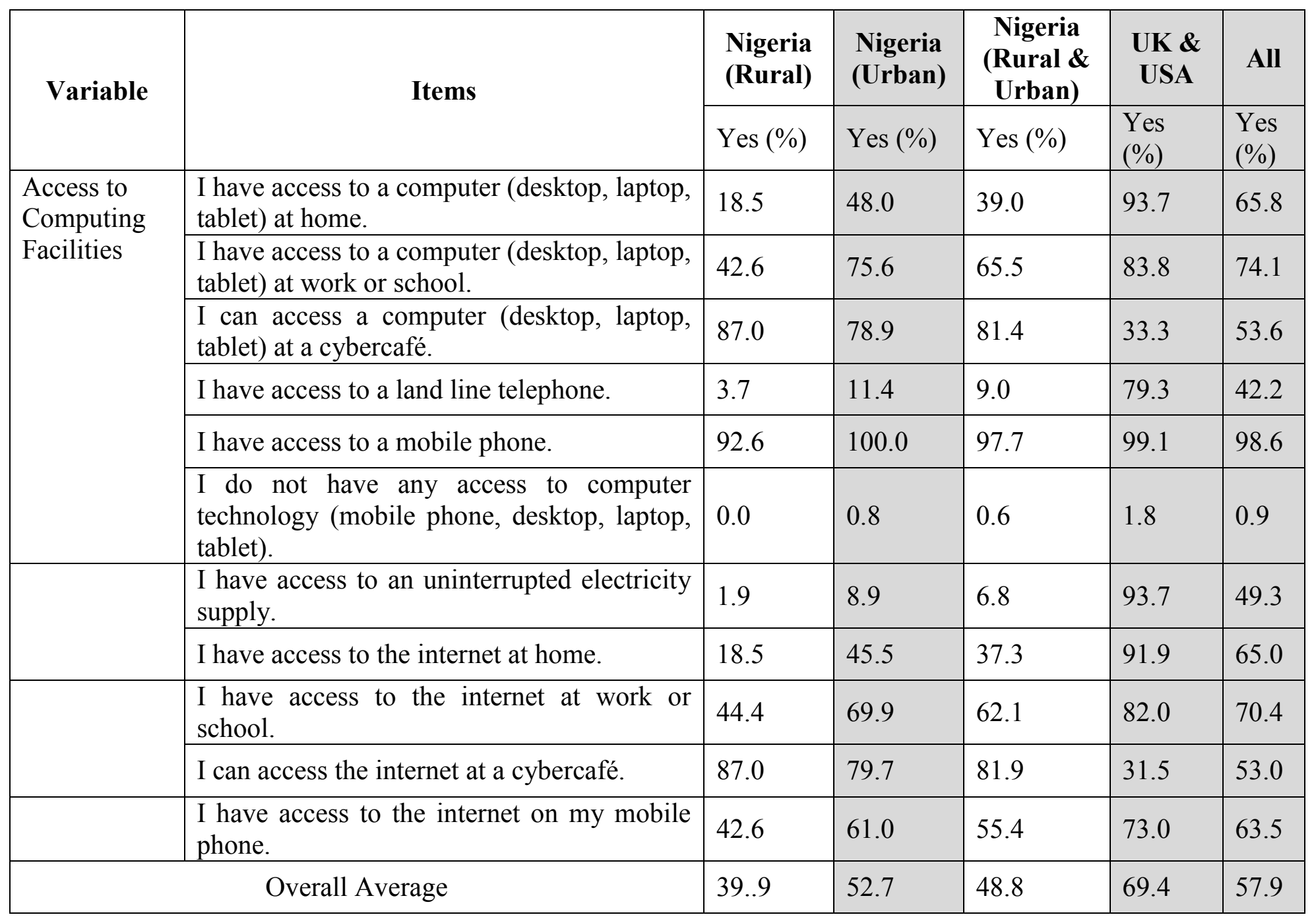

Table 3: Access to computing facilities 


\subsubsection{Internet Experience}

Internet experience was measured using six items shown in Table 4. An overall mean of 2.95 suggests that the respondents were occasional users of technology. However, this figure hides the higher level of specific experience and use, for example, "how often do you use the internet?" (mean $=4.02)$, and the percentage $(100 \%)$ who said that they were occasional, frequent or very frequent users of the internet. This is similar for online shopping (53\%) and online banking (71.5\%); however, in each of these contexts, the largest groups were in the occasional category. Furthermore, the respondents' use of the internet at school was relatively low (mean $=2.21)$ compared to their use at home $($ mean $=3.22)$ and work $($ mean $=2.70)$. Generally, the respondents' use of the internet at work, home or school fell into the occasional category.

\begin{tabular}{|c|c|c|c|c|c|c|c|}
\hline \multirow{2}{*}{ Variable } & \multirow{2}{*}{ Items } & \multirow{2}{*}{ Mean } & (1) & (2) & (3) & (4) & (5) \\
\hline & & & (\%) & $\%)$ & $\%)$ & $(\%)$ & $\%)$ \\
\hline \multirow{6}{*}{$\begin{array}{l}\text { Previous } \\
\text { Internet } \\
\text { Experience }\end{array}$} & How often do you use the internet & 4.02 & 0.00 & 0.00 & 31.30 & 35.60 & 33.10 \\
\hline & $\begin{array}{l}\text { How often do you use the internet for } \\
\text { online shopping }\end{array}$ & 2.56 & 27.10 & 19.90 & 29.60 & 16.80 & 6.60 \\
\hline & $\begin{array}{l}\text { How often do you use the internet for } \\
\text { online banking }\end{array}$ & 3.00 & 10.30 & 18.20 & 41.30 & 21.40 & 8.80 \\
\hline & $\begin{array}{l}\text { How often do you use the internet at } \\
\text { work }\end{array}$ & 2.70 & 39.90 & 5.60 & 14.00 & 25.10 & 15.40 \\
\hline & $\begin{array}{l}\text { How often do you use the internet at } \\
\text { home }\end{array}$ & 3.22 & 31.10 & 1.10 & 10.50 & 29.10 & 28.20 \\
\hline & $\begin{array}{l}\text { How often do you use the internet at } \\
\text { school }\end{array}$ & 2.21 & 54.40 & 7.10 & 12.00 & 16.20 & 10.30 \\
\hline & Overall Average & 2.95 & 27.13 & 8.65 & 23.12 & 24.03 & 17.07 \\
\hline
\end{tabular}

Key: 'never (1), rarely (2), occasionally (3), frequently (4), very frequently (5).

Table 4: Internet experience 


\subsubsection{E-government Experience}

E-government experience was measured using three items shown in Table 5. In terms of e-government services, there was evidence of relatively high use. When asked the question, "how often do you use e-government services?", most $(62.1 \%)$ were either occasional, frequent, or very frequent users of the e-government service. Generally, the respondents' use of the e-government for either transaction or to communicate with government fell into the occasional category.

\begin{tabular}{|c|c|c|c|c|c|c|c|}
\hline \multirow{2}{*}{ Variable } & \multirow{2}{*}{ Items } & \multirow{2}{*}{ Mean } & (1) & (2) & (3) & (4) & (5) \\
\hline & & & $(\%)$ & $\%)$ & $\%)$ & $(\%)$ & $\%)$ \\
\hline \multirow{3}{*}{$\begin{array}{l}\text { Previous } \\
\text { E-government } \\
\text { Experience }\end{array}$} & $\begin{array}{l}\text { How often do you use e-government } \\
\text { services }\end{array}$ & 2.80 & 1.40 & 36.50 & 45.30 & 14.00 & 2.80 \\
\hline & $\begin{array}{l}\text { How often do you conduct financial } \\
\text { transaction online through } \\
\text { e-government services }\end{array}$ & 2.64 & 2.30 & 45.60 & 40.10 & 10.00 & 2.00 \\
\hline & $\begin{array}{l}\text { How often do you communicate with } \\
\text { government agencies through their } \\
\text { official website }\end{array}$ & 2.74 & 2.30 & 39.60 & 42.70 & 13.10 & 2.30 \\
\hline \multicolumn{2}{|r|}{ Overall Average } & 2.73 & 2.00 & 40.57 & 42.70 & 12.37 & 2.36 \\
\hline
\end{tabular}

Key: 'never (1), rarely (2), occasionally (3), frequently (4), very frequently (5).

\section{Table 5: E-government experience}

\subsubsection{Comparing Internet and e-government use in different locations}

The comparison of Nigeria Rural, Nigeria Urban, Nigeria (Rural \& Urban) and the UK and USA respondents' internet and e-government experience is shown in Table 6 and 7 respectively. Table 6 , the overall mean of 2.03 suggests that the respondents living in both the Nigeria rural and Nigeria urban categories are occasional users of technology. However, this figure conceals the higher level of experience in relation to use of the Internet $($ mean $=$ 3.65). However, the frequency of use of online shopping (mean $=1.82)$ and online banking $($ mean $=2.61)$ is lower.

The Nigeria rural and Nigeria urban respondents' use of the internet at school was relatively low $($ mean $=1.98)$ compared to their use at home $($ mean $=2.33)$ and work (mean $=2.38)$. Generally, the respondents use of the 
internet at work and home fell into the frequent category, while their use of the internet at school fell into the occasional category.

In table 7 , the frequency of use of e-government services $($ mean $=2.52)$. The Nigeria rural and Nigeria urban respondents' use of the e-government to conduct financial transaction was occasional $($ mean $=2.41)$ and likewise use of e-government to communicate with government means was 2.46. Generally, the respondents use of the egovernment fell into the occasional category.

\begin{tabular}{|c|c|c|c|c|c|}
\hline \multirow[b]{2}{*}{ Variable } & \multirow[b]{2}{*}{ Items } & \multicolumn{4}{|c|}{ Mean } \\
\hline & & $\begin{array}{l}\text { Nigeria } \\
\text { (Rural) }\end{array}$ & $\begin{array}{l}\text { Nigeria } \\
\text { (Urban) }\end{array}$ & $\begin{array}{c}\text { Nigeria } \\
\text { (Rural \& } \\
\text { Urban) }\end{array}$ & $\begin{array}{c}\text { UK \& } \\
\text { USA }\end{array}$ \\
\hline \multirow{6}{*}{$\begin{array}{l}\text { Previous } \\
\text { Internet } \\
\text { Experience }\end{array}$} & How often do you use the internet & 3.33 & 3.79 & 3.65 & 4.38 \\
\hline & How often do you use the internet for online shopping & 1.41 & 2.01 & 1.82 & 3.41 \\
\hline & How often do you use the internet for online banking & 2.19 & 2.80 & 2.61 & 3.50 \\
\hline & How often do you use the internet at work & 1.85 & 2.62 & 2.38 & 3.21 \\
\hline & How often do you use the internet at home & 1.72 & 2.60 & 2.33 & 4.11 \\
\hline & How often do you use the internet at school & 1.65 & 2.12 & 1.98 & 2.59 \\
\hline & Overall Average & 2.03 & 2.66 & 2.46 & 3.53 \\
\hline
\end{tabular}

Table 6: Internet experiences (comparing Nigeria Rural, Nigeria Urban, Nigeria [Rural \& Urban] and the UK and the USA) 


\begin{tabular}{|c|l|c|c|c|c|}
\hline \multirow{2}{*}{ Variable } & \multicolumn{2}{|c|}{ Items } & \multicolumn{4}{c|}{ Mean } \\
\cline { 3 - 6 } & & $\begin{array}{c}\text { Nigeria } \\
\text { (Rural) }\end{array}$ & $\begin{array}{c}\text { Nigeria } \\
\text { (Urban) }\end{array}$ & $\begin{array}{c}\text { Nigeria } \\
\text { (Rural \& } \\
\text { Urban) }\end{array}$ & $\begin{array}{c}\text { UK \& } \\
\text { USA }\end{array}$ \\
\hline \multirow{2}{*}{$\begin{array}{l}\text { Previous } \\
\text { E-government } \\
\text { Experience }\end{array}$} & How often do you use e-government services & 2.39 & 2.58 & 2.52 & 3.10 \\
\cline { 2 - 7 } & $\begin{array}{l}\text { How often do you conduct financial transaction } \\
\text { online through e-government services }\end{array}$ & 2.31 & 2.46 & 2.41 & 2.89 \\
\cline { 2 - 7 } & $\begin{array}{l}\text { How often do you communicate with government } \\
\text { agencies through their official website }\end{array}$ & 2.46 & 2.46 & 2.46 & 2.97 \\
\hline \multicolumn{1}{|c|}{ Overall Average } & 2.39 & 2.50 & 2.46 & 2.99 \\
\hline
\end{tabular}

Table 7: E-government experiences (comparing Nigeria Rural, Nigeria Urban, Nigeria [Rural \& Urban] and the UK and the USA)

\subsection{Model testing}

Table 8 and Figure 2 shows the results of the hypothesis testing. It demonstrates that most of the hypotheses were supported. Those that were not all related to e-government experience, and findings suggest that Location (rural/urban) (H3), Gender (H9) and Age (H12) do not affect e-government experience. Interestingly, all other variables did affect e-government experience although the effect size was small for Location (Inter-country) (H6) and for Education (H15). Other hypotheses that were supported, but with a small effect size included those relating to the effect of gender and age on access to computing facilities $(\mathrm{H} 7, \mathrm{H} 11)$ and previous internet experience (H8, H10). Perhaps most interestingly, the factors where there is a strong influence between the demographic factor and all three dimensions of the e-government digital divide are income and employment, which are socio-economic variables. Education also strongly influences access to computing facilities (H13) and previous internet experience (H14), although the effect size for previous e-government experience is small (H15). Not surprisingly, given the widespread acknowledgement regarding the difference in information and communications infrastructure between developing countries and developed countries, (Chinn \& Fairlie, 2010) there is strong evidence that country location makes a significant difference to previous internet experience and access to computing facilities (H1, H2, $\mathrm{H} 4, \mathrm{H} 5)$. 


\begin{tabular}{|c|c|c|c|c|c|c|c|}
\hline Hypothesis & Variable & Statistical & \multicolumn{2}{|l|}{ Path Coefficient } & Results & Effect & Effect \\
\hline H1 & \multirow{6}{*}{ Location } & t-test & $\begin{array}{l}\text { Location (rural / urban) affects } \\
\text { access to computing facilities }\end{array}$ & 0.000 & Supported & 0.12 & Medium \\
\hline $\mathrm{H} 2$ & & t-test & $\begin{array}{l}\text { Location (rural / urban) affects } \\
\text { internet experience }\end{array}$ & 0.000 & Supported & 0.10 & Medium \\
\hline $\mathrm{H} 3$ & & t-test & $\begin{array}{l}\text { Location (rural / urban) affects } \\
\text { e-government experience }\end{array}$ & 0.263 & $\begin{array}{l}\text { Not } \\
\text { supported }\end{array}$ & $\begin{array}{l}\text { Not } \\
\text { Applicable }\end{array}$ & $\begin{array}{l}\text { Not } \\
\text { Applicable }\end{array}$ \\
\hline H4 & & t-test & $\begin{array}{l}\text { Location (inter-country) affects } \\
\text { access to computing facilities }\end{array}$ & 0.000 & Supported & 0.29 & Large \\
\hline H5 & & t-test & $\begin{array}{l}\text { Location (inter-country) affects } \\
\text { internet experience }\end{array}$ & 0.000 & Supported & 0.31 & Large \\
\hline H6 & & t-test & $\begin{array}{l}\text { Location (inter-country) affects e- } \\
\text { government experience }\end{array}$ & 0.000 & Supported & $*_{-} 0.12$ & Small \\
\hline H7 & \multirow{3}{*}{ Gender } & t-test & $\begin{array}{l}\text { Gender affects access to computing } \\
\text { facilities }\end{array}$ & 0.026 & Supported & 0.01 & Small \\
\hline H8 & & t-test & Gender affects internet experience & 0.043 & Supported & 0.01 & Small \\
\hline H9 & & t-test & $\begin{array}{l}\text { Gender affects e-government } \\
\text { experience }\end{array}$ & 0.199 & $\begin{array}{l}\text { Not } \\
\text { supported }\end{array}$ & $\begin{array}{l}\text { Not } \\
\text { Applicable }\end{array}$ & $\begin{array}{l}\text { Not } \\
\text { Applicable }\end{array}$ \\
\hline H10 & \multirow{3}{*}{ Age } & Anova & $\begin{array}{l}\text { Age affects access to computing } \\
\text { facilities }\end{array}$ & 0.001 & Supported & 0.04 & Small \\
\hline H11 & & Anova & Age affects internet experience & 0.001 & Supported & 0.04 & Small \\
\hline H12 & & Anova & $\begin{array}{l}\text { Age affects e-government } \\
\text { experience }\end{array}$ & 0.090 & $\begin{array}{l}\text { Not } \\
\text { supported }\end{array}$ & $\begin{array}{l}\text { Not } \\
\text { Applicable }\end{array}$ & $\begin{array}{l}\text { Not } \\
\text { Applicable }\end{array}$ \\
\hline H13 & \multirow{3}{*}{ Education } & Anova & $\begin{array}{l}\text { Education affects access to } \\
\text { computing facilities }\end{array}$ & 0.000 & Supported & 0.19 & Large \\
\hline H14 & & Anova & $\begin{array}{l}\text { Education affects internet } \\
\text { experience }\end{array}$ & 0.000 & Supported & 0.20 & Large \\
\hline H15 & & Anova & $\begin{array}{l}\text { Education affects e-government } \\
\text { experience }\end{array}$ & 0.000 & Supported & 0.05 & Small \\
\hline H16 & \multirow{3}{*}{ Employment } & Anova & $\begin{array}{l}\text { Employment affects access to } \\
\text { computing facilities }\end{array}$ & 0.000 & Supported & 0.15 & Large \\
\hline H17 & & Anova & $\begin{array}{l}\text { Employment affects internet } \\
\text { experience }\end{array}$ & 0.000 & Supported & 0.11 & Medium \\
\hline H18 & & Anova & $\begin{array}{l}\text { Employment affects e-government } \\
\text { experience }\end{array}$ & 0.002 & Supported & 0.05 & Small \\
\hline H19 & \multirow{3}{*}{ Income } & Anova & $\begin{array}{l}\text { Income affects access to computing } \\
\text { facilities }\end{array}$ & 0.000 & Supported & 0.20 & Large \\
\hline $\mathrm{H} 20$ & & Anova & Income affects internet experience & 0.000 & Supported & 0.20 & Large \\
\hline $\mathrm{H} 21$ & & Anova & $\begin{array}{l}\text { Income affects e-government } \\
\text { experience }\end{array}$ & 0.000 & Supported & & Medium \\
\hline
\end{tabular}

Table 8: Digital divide dimensions hypotheses summary

Insert Figure 2 here 


\section{Discussion}

This section discusses the findings in relation to earlier research, with a view to drawing out new insights and indentifying the contribution of this study. The section commences with reflections on the insights from the descriptive statistics, and then moves on to consider implications of the hypothesis testing.

\subsection{Describing Access and Experience}

The descriptive statistics provide an interesting profile of the levels of access to computing facilities and experience of using the Internet and e-government websites. The data on access confirms various previous studies regarding access to e-services in developing countries. For example, in terms of access to technology, almost all of the sample had access to a mobile phone, less than half had access to a landline telephone, and $50 \%$ had access to a computer, but importantly, only half had access to an uninterrupted electricity supply, and probably most that did were located in the US and the UK. Analysis on the basis of location showed a very low level of access to a landline telephone for both groups in Nigeria, as well as much more limited access to a computer. For users in Nigeria access through a cybercafé, emerged as important. Other commentators have also reported on the challenges facing developing countries regarding developing their information and communication technology infrastructure (Vu, 2011; Gomez \& Panther, 2012). More specifically, Thompson \& Walsham (2010) demonstrate that Africa faces a high level of inequality, a weak IT communication system, particularly in rural areas, and a lack of willingness to invest in ICT and address related issues on the part of governments, whilst Nkwe (2012) and Nkohkwo \& Islam (2013) make a link between poor internet infrastructure and a digital divide regarding egovernment services.

In terms of Internet and e-government experience overall users could be categorised as occasional users of technology, however, on the other hand, all respondents indicated that they were occasional, frequent or very frequent users of the internet. Comparing users in Nigeria and elsewhere, there is a lower level of frequency of use 
for all of the questions in Table 6 and 7, and in most instances the frequency of use in rural Nigeria is lower than in urban Nigeria. This lower level of frequency of use is consistent with the challenges associated with access, as discussed above and with the low levels of internet utilization and restricted development of e-commerce in developing countries reported in various other studies (Bertot, 2003; Akanbi \& Akanbi, 2012; Forum for East AsiaLatin America Cooperation [FEALAC], 2014).

\subsection{The Multi-Dimensional Digital Divide and the impact of demographic factors.}

The central contribution of this article is to propose a model of the multi-dimensional digital divide that embraces both the central aspects of the digital divide and the demographic factors that affect it. The relationships between these variables are explored in relation to the users of a specific e-government portal associated with a large developing country. In this research, we have conceptualized the digital divide as having two core dimensions, relating respectively to previous internet experience (skills) and access to computing facilities (access), both of which have been regarded by other authors as core to the concept of the digital divide. In addition, since our research focuses on e-government, and in keeping with agendas that posit that e-government can enhance computer literacy (Zinyama \& Nhema, 2016), we have also used the dimension, previous e-government experience. We have demonstrated that with a few exceptions, location, gender, age, education, employment and income impact on one or more of the three dimensions of the digital divide used in this study. As discussed above, effect sizes vary, and demographic variables appear to have the least effect on previous e-government experience. On this latter point, we

suspect this might be due to the relatively low level of engagement with e-government services, for all demographic groups. But even this finding has an interesting message regarding conducting research on information systems when users may have a more limited level of familiarity with those system, that researchers' or policy makers' might aspire to them having.

The following paragraphs discuss in more detail the extent of alignment between this study and earlier studies and associated implications. The discussion follows the order of variables in Figure 2. 
Hypotheses relating to location were designed to explore whether earlier research suggesting that there is a digital divide based on (a) whether users live in a rural or urban location $(\mathrm{H} 1, \mathrm{H} 2, \mathrm{H} 3)$ or (b) whether they live in a developing or developed country (H4, H5, H6). In respect of living in an urban or rural area, there is a significant link between location and previous internet experience and access to computing facilities (H1, H2). This is consistent with other research that has identified a lower level of internet use in rural areas, than in urban areas. There is evidence that this divide has been consistent over many years, with early research from Hindman (2000) and Norris (2000) having been confirmed more recently by Park \& Kim (2015) and Banihahemi \& Rajaei (2015), who refer to the persistent digital divide between urban and rural Internet users. Park \& Kim (2015) and Banihahemi \& Rajaei (2015) suggest that one reason for this persistent digital divide might be related to relative poverty in rural areas, whilst others point to concentration of Public Internet access points in urban areas (Furuholt and Kristiansen, 2007). There is also considerable evidence to demonstrate the persistence of a digital divide between developed and developing countries (e.g. Rouvien, 2006; Warschauer, 2012). This study shows that this divide applies to access to computing facilities and previous Internet experience for people living in Nigeria relative to those living in the US and the UK, although the gulf is narrower between these two groups than in the rural/urban divide within Nigeria. No other studies have compared these three groups, and thereby facilitated an analysis of both within and between country digital divides within one study. In relation to their previous experience with e-government there is no evidence of a significant difference between groups within Nigeria (urban or rural) (H3). This may be because all respondents share experience of using the NIS portal, whose use is mandatory for those wishing to travel in and out of Nigeria. On the other hand, NIS portal users in developed countries had more e-government experience than urban users in Nigeria (H6), probably because they are exposed to e-government services in developed countries.

Gender and age are two demographic characteristics that have been much studied in relation to access to and use of information technology facilities. In respect of gender, there is a considerable body of evidence to evince that 
women are less likely to use computing facilities than men (Wasserman \& Richmond-Abbott, 2005) and that this is especially the case in developing countries (Antonio \& Tuffley, 2014). This research confirms that this is the case for users of the NIS Portal, although the effect size is small, which might demonstrate that gender is not as important as suggested by some previous researchers. Interestingly, for example, Hilbert (2011) found that taking age into consideration shows that younger women have higher levels of computer usage than men of a similar age. In this research, the findings for age are comparable to those for gender. In other words, age affects both previous Internet experiences and access to computing facilities (H10, H11), but effect sizes are small, possibly suggesting this is less significant amongst respondents in this study, than might by suggested by the extensive body of research that contend the interest in and use of technology is lower amongst older people (e.g. Heart \& Kalderon, 2013; Idowu \& Adagunodo, 2005; Thayer \& Ray, 2006). However, interpreting the effect of age on the digital divide is complex because its effect is often inter-related with social economic variables, such as income, and as Lenhart at al. (2010) suggest the most common online activities are to some extent age dependent.

Finally, it is important to consider the effect of the socio-demographic variables of education, employment and income. All of the hypotheses for education, employment and income are supported, although the effect size varies; in particular, the effect size is small for the link between education and employment, respectively, and previous e-government experience. Broadly speaking, better educated, employed, and higher income respondents have greater access to computing facilities, which, in turn is likely to lead to a higher level of previous Internet experience. Such findings are not new and are consistent with findings from many other studies. For example, education has been shown to be the most consistent global predictor in measuring experience and access to internet technology (Chinn \& Fairlie, 2006; Kiiski \& Pohjola, 2002; Vicente \& López, 2011; Wilson, Walin \& Reiser, 2003; Zhong, 2011; Puspitasari, \& Ishii, 2016). Similarly, previous research has indicated that the level of computing and internet access depends heavily on employees' type of work and the need for the use of technology in the workplace (Anderson, 2001; Fountain, 2005; Rustad \& Paulsson, 2005). Finally, previous research has also 
shown that income affects internet access and experience (Chakraborty \& Bosman, 2005; Fuchs, 2008; Servon and Nelson, 2001; Warschauer, 2002).

\subsection{Summary}

Figure 3 presents the final model for this research. The digital divide is represented in terms of the three dimensions: access to computing facilities, previous Internet experience and previous e-government experience. Overall, Figure 3 shows that amongst the users of the NIS portal, there is a multi-dimensional digital divide with demographic and social-economic factors, as well as location affecting e-government users' access to computing facilities, internet experience, and e-government experience. In addition, three of the demographic variables, location (rural/urban), gender and age only show significant impact on previous Internet experience and access to computing facilities, and not on previous e-government experience. Overall, this research offers insights into the complexity of the digital divide, and the limitations of research that considers only one dimension of the digital divide, such as gender or education.

\section{Insert Figure 3 here}

\section{Conclusions}

This study proposes the Multi-dimensional Digital Divide Model, which shows the relationships between the dimensions of the digital divide in the context of an e-government service, viz, access to computing facilities, previous internet experience and previous e-government experience and demographic variables. In the context of a sample who had used the NIS e-government service it can be seen that demographic (age, gender), social-economic (education, employment, income) and geographical location (rural and urban locations, developing and developed countries) factors affect the extent of the digital divide. Importantly, the choice of the NIS service as a basis for this study allows for comparisons to be made between users of the service resident both in Nigeria and elsewhere in the world. 
Overall, the study demonstrates that there is a significant digital divide between users inside and outside of Nigeria and between those living in rural and urban Nigeria. This study provides further evidence that access to technology and online services, in general, is at a very much lower ebb, than in, for instance the US and the UK, and that this has consequences for the frequency of use of such services, whether they be online banking, online shopping or egovernment. Importantly, users in Nigeria were much more dependent than users elsewhere on mobile devices and cybercafes for access to all online services, including e-government. In addition, the intermittent electricity supply is a considerable impediment to online service use.

In terms of the practical implications of this study, this study provides yet further evidence of the importance of infrastructure development in developing countries in order to ensure the success of e-government services. Without such developments, e-government services have the potential to reproduce, and even magnify existing social disparities. More specifically, it is suggested that in investing in and developing their e-government policies and infrastructure, it is essential that there is further consideration of the development of mobile-based egovernment services. Currently, users are typically accessing a service designed to be accessed through landline computers through mobile technologies. For users in Nigeria, this is because they either do not have access to landline based computers or because the access they do have is significantly affected by intermittent electricity supply. There is also a very evident disparity in relation to users in rural areas in Nigeria, when compared with those either in US/UK or urban Nigeria, in terms of all three dimensions of the digital divide, access, internet experience and e-government experience. This suggests that Nigeria needs to prioritize investment in technology (and power supply) infrastructure in rural areas, possibly through the enhancement of the quality of cybercafes, which, whilst not having some of the immediacy of access in homes, offer the benefit of availability of support in working with computing technologies. Finally, on the basis of the identification of the multi-dimensional digital divide identified and profiled in this study, it is important for government policy to acknowledge and respond to the multiplicity of digital divides., They need to acknowledge that groups experiencing a digital divide on one 
dimension (e.g. as a result of their gender) may also experience other digital divides (e.g. as a result of education and/or employment). Nuanced policy responses that work with communities to understand and respond to these subtleties have greater potential to be successful than large scale one-size-fits-all approaches.

This study has one very important limitation, which actually strengthens the message that it communicates. The sample for the study is drawn from the users of the NIS portal. These are people who have the wealth to travel in and out of Nigeria, and the ability not only to make use of the NIS portal, but also to complete an online questionnaire. It is not representative of the social spectrum of citizens in Nigeria. Yet, this research has still identified a very noticeable digital divide. We suggest that the digital divide might be even more significant for users in lower socio-economic groups, and in rural areas, both of which are not strongly represented in this study. There are challenges associated with conducting research into the digital divide amongst communities in which large numbers of potential respondents are non-users of e-government. Nevertheless, the insights that such studies might generate could be very valuable because it is these groups that are often the target of government policy.

Moving forward, there is considerable scope for further studies into the digital divide in Nigeria and other parts of Africa, with a specific focus on the extent and nature of the digital divide, and how it can be identified and measured. It would also be useful to explore the impact of e-government initiatives on the digital divide, possibly through a longitudinal study and to explore the uptake and impact of the different types of e-government services, such as, perhaps, those associated with education or health. Finally, with the purpose of theoretical development of the notion of the digital divide, it is important to explore further the interplay between demographic and socioeconomic variables in use of e-government services.

\section{References}

Abdulkareem, A.K. (2015). Challenges of e-government implementation in the Nigerian public service. Journal of Creative Writing, 1(4), 45-56.

Adeniran, A. (2008). The internet and emergence of yahoo boys sub-culture in Nigeria. International Journal of 25 
Cyber Criminology, 2(2), 368-381.

Adeyemo, A. (2011). E-government implementation in Nigeria: An assessment of Nigeria's global e-gov ranking. Journal of Internet and Information Systems, 2(1), 11-19.

Akanbi, B. \& Akanbi, C. (2012). Bridging the digital divide and the impact on poverty in Nigeria. Computing, Information Systems \& Development Informatics, 3(4).

Akkeren, J. \& Cavaye, A. (1999). Factors affecting entry-level internet technology adoption by small business in Australia: an empirical study. In: Proceedings of the 10th Australasian Conference on Information Systems, Wellington, New Zealand. [online] Wellington, New Zealand.

http://www.acs.org.au/act/events/io1999/akkern.html /Accessed 17.03.16.

Akman, I., Yazici, A., Mishra, A. \& Arifoglu, A. (2005). E-government: A global view and an empirical evaluation of some attributes of citizens. Government Information Quarterly, 22(2), 239-257.

Akunyili, D. (2010). ICT and e-government in Nigeria. / https://goafrit.wordpress.com/2010/06/12/ict-and-egovernment-in-nigeria-prof-akunyili//Accessed 11.04.16.

Almarabeh, T. \& AbuAli, A. (2010). A general framework for e-government: definition maturity challenges, opportunities, and success. European Journal of Scientific Research, 39(1), 29-42.

AL-Rababah, B. \& Abu-Shanab, E. (2010). E-government and gender digital divide: the case of Jordan. International Journal of Electronic Business Management, 8(1), 1-8.

Al-Shboul, M., Rababah, O., Al-Shboul, M., Ghnemat, R. \& Al-Saqqa, S. (2014). Challenges and factors affecting the implementation of e-government in Jordan. JSEA, 07(13), 1111-1127.

Anderson, K. (2001). Internet use among college students: an exploratory study. Journal of American College Health, 50(1), 21-26.

Antonio, A. \& Tuffley, D. (2014). The gender digital divide in developing countries. Future Internet, 6(4), 673687.

Avi, A., Bakht, H. \& Bukoye, O. (2015). Adoption of e-governance and its implications in developing countries. / Ssrn.com. / http://ssrn.com/abstract=2686895 /Accessed 16.03.16.

Banihashemi, S. \& Rejaei, Z. (2015). Analysis of the digital divide in Asia - Islamic countries: a topsis approach. Journal of Asian Scientific Research, 5(4), 165-176.

Belanger, F. \& Carter, L. (2009). The impact of the digital divide on e-government use. Communications of the 
ACM, 52(4), 132-135.

Bertot, J. (2003). The multiple dimensions of the digital divide: more than the technology 'haves' and 'have nots'. Government Information Quarterly, 20(2), 185-191.

Brandtzæg, P., Heim, J. \& Karahasanović, A. (2011). Understanding the new digital divide -A typology of Internet users in Europe. International Journal of Human-Computer Studies, 69(3), 123-138.

Chakraborty, J. \& Bosman, M. (2005). Measuring the digital divide in the United States: race, income, and personal computer ownership. The Professional Geographer, 57(3), 395-410.

Chatfield, A. \& Alhujran, O. (2009). A cross-country comparative analysis of e-government service delivery among Arab countries. Information Technology for Development, 15(3), 151-170.

Chen, W. \& Wellman, B. (2004). The global digital divide within and between countries. IT and Society, 1(7), 3945.

Chinn, M. \& Fairlie, R. (2010). ICT use in the developing world: an analysis of differences in computer and internet penetration. Review of International Economics, 18(1), 153-167.

Chinn, M. \& Fairlie, R. (2006). The determinants of the global digital divide: a cross-country analysis of computer and internet penetration. Oxford Economic Papers, 59(1), 16-44.

Cohen, J. (1988). Statistical power analysis for the behavioural sciences. Hillside. NJ: Lawrence Earlbaum Associates.

Creswell, J. (2009). Research design: qualitative, quantitative and mixed methods. (3rd ed.). Thousand Oaks, Calif.: Sage Publications, 5-17.

Cullen, R. (2001). Addressing the digital divide. Online Information Review, 25(5), 311-320.

Dada, D. (2006). The failure of e-government in developing countries: A literature review. The Electronic Journal of Information Systems in Developing Countries, 26(7), 1-10.

Fallows, D. (2005). How women and men use the internet. Pew Research Center's Internet \& American Life Project. http://www.pewinternet.org/2005/12/28/how-women-and-men-use-the-internet/ Accessed 17.03.16.

Fatile, J.O. (2012). Electronic governance: myth or opportunity for Nigerian public administration? International Journal of Academic Research in Business and Social Sciences. 2 (9) / http://www.hrmars.com/admin/pics/1104.pdf / Accessed 11.04.16. 
FEALAC. IT revolution for developing countries (bridging the digital divide). Mofa.go.jp.(2014).

http://www.mofa.go.jp/region/latin/fealac/it.html /Accessed 13.03.16.

Fountain, C. (2005). Finding a Job in the Internet Age. Social Forces, 83(3), 1235-1262.

Fuchs, C. (2008). The role of income inequality in a multivariate cross-national analysis of the digital divide. Social Science Computer Review, 27(1), 41-58.

Furuholt, B. \& Kristiansen, S. (2007). A rural-urban digital divide? Regional aspects of internet use in Tanzania. In: Proceedings of the 9th International Conference on Social Implications of Computers in Developing Countries.

Gomez, R. \& Pather, S. (2012). ICT evaluation: are we asking the right questions?. The Electronic Journal of Information Systems in Developing Countries, 50, 1-14.

Guillen, M. \& Suarez, S. (2005). Explaining the global digital divide: economic, political and sociological drivers of cross-national internet use. Social Forces, 84(2), 681-708.

Hall, T. \& Owens, J. (2011). The digital divide and e-government services. In: Proceedings of the 5th International Conference on Theory and Practice of Electronic Governance ICEGOV'11. Elsa Estevez and Marijn Janssen (Eds.), ACM, New York, 37-44.

Hassan, H., Shehab, E. \& Peppard, J. (2011). Recent advances in e-service in the public sector: state-of-the-art and future trends. Business Process Mgmt Journal, 17(3), 526-545.

Heart, T. \& Kalderon, E. (2013). Older adults: Are they ready to adopt health-related ICT?. International Journal of Medical Informatics, 82(11), e209-e231.

Hermana, B. \& Silfianti, W. (2011). Evaluating e-government implementation by local government: Digital Divide in Internet Based Public Services in Indonesia. International Journal of Business and Social Science, 2(3), 156-163.

Hilbert, M. (2011). Digital gender divide or technologically empowered women in developing countries? A typical case of lies, damned lies, and statistics. Women's Studies International Forum, 34(6), 479-489.

Hilbert, M. (2011). The end justifies the definition: The manifold outlooks on the digital divide and their practical usefulness for policy-making. Telecommunications Policy, 35(8), 715-736.

Hindman, D. (2000). The rural-urban digital divide. Journalism \& Mass Communication Quarterly, 77(3), 549-560. 
Hoofnagle, C., King, J., Li, S. \& Turow, J. (2010). How different are young adults from older adults when it comes to information privacy attitudes and policies?. SSRN Electronic Journal. / http://ssrn.com/abstract=1589864 /Accessed 16.03.16.

IBM Corp, (2013). IBM SPSS statistics for windows. Version 22.0. Armonk, NY: IBM.

Idowu, A., Idowu, P. \& Adagunodo, E. (2005). Empirical study on information and communication technology and youth in a developing country: Nigeria as a case. International Journal of Information Technology \& Decision Making, 4(2), 297-309.

Idowu, B. \& Adagunodo, R. (2004). Gender difference in computer literacy among Nigeria undergraduates' students. The African Symposium. An On-line Educational Research Journal, 4(3).

Imhonopi, D. and Urim, U.M. (2015). Information and communication technology (ICT) and governance in Nigeria: challenges and prospect. Journal of Humanities, Social Science and Creative Arts, 6(2), 1-14.

Jidaw System Ltd. Nigeria's IT policy, Nigeria ICT4D plan National Information Technology Development Agency (NITDA)". (2011). http://www.jidaw.com/policy.html/ Accessed 17.12.06.

Jung, Y. (2011). Understanding the role of sense of presence and perceived autonomy in users' continued use of social virtual worlds. Journal of Computer-Mediated Communication, 16(4), 492-510.

Jurich, S. (2000). The information revolution and the digital divide. TechKnowLogia. / http://www.techknowlogia.org/TKL_Articles/PDF/97.pdf /Accessed 9.03.16.

Kanat, I. \& Ozkan, S. (2009). Explaining citizen adoption of government to citizen services: a model based on theory of planned behaviour (TBP). In: Proceedings of European and Mediterranean Conference on Information Systems 2009 (EMCIS2009). /

http://citeseerx.ist.psu.edu/viewdoc/download?doi=10.1.1.501.8037\&rep=rep1\&type=pdf /Accessed 6.03.16.

Khan, G., Moon, J., Zo, H. \& Rho, J. (2010). Civil conflict, digital divide, and e-government service adoption: a conflict theory approach. World Academy of Science, Engineering \& Technology, 42, 537.

Kiiski, S. \& Pohjola, M. (2002). Cross-country diffusion of the internet. Information Economics and Policy, 14(2), 297-310.

Kim, D., Ferrin, D. \& Rao, H. (2008). A trust-based consumer decision-making model in electronic commerce: the role of trust, perceived risk, and their antecedents. Decision Support Systems, 44(2), 544-564.

Kuboye, B., Alese, B. \& Imasuen, F. (2012). A twin approach to internet service provision in sparse rural 
community in Nigeria. International Journal of Networks and Communications, 2(5), 132-137.

Lenhart, A., Purcell, K., Smith, A. \& Zickuhr, K. (2010). Social media \& mobile internet use among teens and young adults. millennials. Pew Internet \& American Life Project.

http://files.eric.ed.gov/fulltext/ED525056.pdf/Accessed 13.03.16.

Loges, W. \& Jung, J. (2001). Exploring the digital divide: internet connectedness and age. Communication Research, 28(4), 536-562.

Min, S. (2010). From the digital divide to the democratic divide: internet skills, political interest, and the secondlevel digital divide in political internet use. Journal of Information Technology \& Politics, 7(1), 22-35.

Morgan, G., Leech, N., Gloeckner, G. \& Barrett, K. (2013). IBM SPSS for introductory statistics: use and interpretation. (5th ed.). New York: Routledge.

Morris, D. \& Morris, J. (2013). Accidental online information acquisition and the digital divide in the 2012 presidential election campaign. Prepared for presentation at the annual meeting of the Western Political Science Association, Seattle, WA. April 17-20.

Mundy, D. \& Musa, B. (2010). Towards a framework for egovernment adoption in Nigeria. http://www.ejeg.com/issue/download.html?idArticle=205 /Accessed 11.03.16.

NCC. Subscriber statistics. (2015)/ http://www.ncc.gov.ng/index.php?option=com_content\&view=article\&id=125:art-statistics-subscriberdata\&catid $=65$ :cat-web-statistics\&Itemid $=73 /$ Accessed 10.03.16.

NCC. Subscriber Statistics (2016). http://www.ncc.gov.ng/stakeholder/statistics-reports/subscriber-data / Accessed 17.12.06.

Nigeria Immigration Service. History of the Nigeria immigration services. (2016). http://www.immigration.gov.ng/index.php?id=3 / Accessed 230.3.16.

Nitzan, I. \& Libai, B. (2011). Social effects on customer retention. Journal of Marketing, 75(6), 24-38.

Nkohkwo, Q. \& Islam, M. (2013). Challenges to the successful implementation of e-government initiatives in subSaharan Africa: A literature review. Electronic Journal of e-Government, 11(2), 53-253.

Nkwe, N. (2012). Egovernment: challenges and opportunities in Botswana. International Journal of Humanities and Social Science., 2(17).

Norris, P. (2000). The worldwide digital divide: information poverty, the internet and development. John F. 
Kennedy School of Government - Harvard University. I

http://www.hks.harvard.edu/fs/pnorris/Acrobat/psa2000dig.pdf / Accessed 5.03.16.

Norris, P. (2006). The world-wide digital divide: information poverty, the internet, and development. Presented at the Annual Meeting of the Political Studies, 1-6.

Nwalo, K. (2000). Collaboration in the provision and utilization of IT facilities for library and information science education in Nigeria. Information Technology In Library and Information Science Education In Nigeria, 3241.

OECD. Understanding the digital divide. (2001). /http://www.oecd.org/sti/1888451.pdf / Accessed 17.03.16.

Oduneye, T. (2015). Research and Reports.

http://www.ncc.gov.ng/index.php?option=com_content\&view=article\&id=1497\&Itemid=67 $/$ Accessed 15.12.06].

Olufemi, F.J (2012). Electronic governance: myth or opportunity for Nigerian public administration. International Journal of Academic Research in Business and Social Sciences, 2(9).

Omeire, E. \& Omeire, C. (2014). New wine in old wine skin: an exploration of major constraints to e-government implementation in Nigeria. European Scientific Journal, 10 (14) / http://eujournal.org/index.php/esj/article/viewFile/3424/3188/ Accessed 11.04.16

Pallant, J. (2010). SPSS survival manual: a step by step guide to data analysis using SPSS. (4th ed.). Maidenhead: Open University Press/McGraw-Hill.

Park, S. \& Kim, G. (2015). Same access, different uses, and the persistent digital divide between urban and rural internet users. Social Science Research Network.

Parra-López, E., Bulchand-Gidumal, J., Gutiérrez-Taño, D. \& Díaz-Armas, R. (2011). Intentions to use social media in organizing and taking vacation trips. Computers in Human Behavior, 27(2), 640-654.

Po-An Hsieh, J., Rai, A. \& Keil, M. (2008). Understanding digital inequality: comparing continued use behavioral models of the socio-economically advantaged and disadvantaged. MIS Quarterly, 32(1), 97-126.

Prahalad, C. (2004). The fortune at the bottom of the pyramid. Harlow: Financial Times Prentice Hall, 1-13.

Premium Times, (2015). Internet usage on Nigeria's GSM networks increases to 81 million - Premium Times Nigeria. http://www.premiumtimesng.com/news/top-news/180597-internet-usage-on-nigerias-gsm-networksincreases-to-81-million.html / Accessed 16.12.06. 
Puspitasari, L. \& Ishii, K. (2016). Digital divides and mobile Internet in Indonesia: impact of smartphones, Telematics and Informatics, 33 (2), 472-483

Reddick, C. (2010). Comparative e-government. New York: Springer.

Rouvinen, P. (2006). Diffusion of digital mobile telephony: are developing countries different?. Telecommunications Policy, 30(1), 46-63.

Rustad, M. \& Paulsson, S. (2005). Monitoring employee e-mail and internet usage: avoiding the omniscient electronic sweatshop:. Insights from Europe. University of Pennsylvania Journal of Labor and Employment Law, 7.

Sellitto, C. \& Martin, B. (2003). Web Site Adoption: A Study of 107 Victorian SME wineries. In: Proceedings of the 9th Ninth Australian World Wide Web (AusWeb) Conference. Sanctuary Cove, Queensland, 23-32.

Servon, L. \& Nelson, M. (2001). Community technology centers: narrowing the digital divide in low-income, urban communities. Journal of Urban Affairs, 23(3\&4), 279-290.

Shirazi, F., Ngwenyama, O. \& Morawczynski, O. (2010). ICT expansion and the digital divide in democratic freedoms: An analysis of the impact of ICT expansion, education and ICT filtering on democracy. Telematics and Informatics, 27(1), 21-31.

Sitawa-Ogutu, J. \& Rege, R. (2010). Bridging the digital divide: a literature review. In: 12th KARI Biennial Scientific Conference. Kenya Agricultural Research Institute,1317-1323.

Sylvester, D. \& McGlynn, A. (2010). The digital divide, political participation, and place. Social Science Computer Review, 28(1), 64-74.

Taylor, T. \& Owusu, E. (2012). Factors affecting internet and e-commerce adoption among small and mediumsized enterprise non-traditional exporters: case studies of Ghanaian handicraft exporters. European Journal of Business and Management, 4(13).

Tayo, O., Thompson, R. \& Thompson, E. (2015). Impact of the digital divide on computer use and internet access on the poor in Nigeria. Journal of Education and Learning, 5(1), 1.

Thayer, S. \& Ray, S. (2006). Online communication preferences across age, gender, and duration of internet use. CyberPsychology \& Behavior, 9(4), 432-440.

The World Factbook, The world factbook: Africa, Nigeria. (2016)./ https://www.cia.gov/library/publications/theworld-factbook/geos/ni.html / Accessed 13.12.16. 
Thompson, M. \& Walsham, G. (2010). ICT research in Africa: need for a strategic developmental focus. Information Technology for Development, 16(2), 112-127.

UN. United Nations e-government survey 2014: e-government for the future we want. (2014) / http://unpan3.un.org/egovkb/Portals/egovkb/Documents/un/2014-Survey/E-Gov_Complete_Survey-2014.pdf 1 Accessed 13.03.16.

van Deursen, A. \& van Dijk, J. (2010). Internet skills and the digital divide. New Media \& Society, 13(6), 893-911.

van Dijk, J. \& Hacker, K. (2003). The digital divide as a complex and dynamic phenomenon. The Information Society, 19(4), 315-326.

Vicente, M. \& Lopez, A. (2011). Assessing the regional digital divide across the European Union-27. Telecommunications Policy, 35(3), 220-237.

Vu, K. (2011). ICT as a source of economic growth in the information age: empirical evidence from the $1996 a ̂ €$ ‘2005 period. Telecommunications Policy, 35(4), 357-372.

Wanasika, I. (2003). In search of global leadership. Journal of International Business and Cultural Studies, 1-17.

Warschauer, M. (2002). Reconceptualizing the digital divide. First Monday, 7(7). http://firstmonday.org/article/view/967/888/ Accessed 11.04.16.

Warschauer, M. (2012). The digital divide and social inclusion | Americas Quarterly. / http://www.americasquarterly.org/warschauer / Accessed 16.03.16.

Wasserman, I. \& Richmond-Abbott, M. (2005). Gender and the internet: causes of variation in access, level, and scope of use. Social Science $Q, 86(1), 252-270$.

White, C. (2012). Digital divide: if you're reading this, you're one of the lucky ones [INFOGRAPHIC]. / http://mashable.com/2012/02/05/digital-divide-infographic/ Accessed 13.03.16

Wilson, K., Wallin, J. \& Reiser, C. (2003). Social stratification and the digital divide. Social Science Computer Review, 21(2), 133-143.

Yonazi, J., Sol, H.\& Albert, B. (2010). Exploring issues underlying citizen adoption of egovernment initiatives in developing countries: the case of Tanzania. Electronic Journal of e-Government, 8(2), 176-188.

Zhong, Z. (2011). From access to usage: the divide of self-reported digital skills among adolescents. Computers \& Education, 56(3), 736-746. 
Zinyama, T. \& Nhema, A. (2016). E-Government and development in Zimbabwe: An Appraisal. Public Policy and Administration Research, 6(2). 